\title{
The Competitiveness of Public Transport
}

\author{
- Poliak Miloś, Poliaková Adela, Mrníková Michaela, Šimurková Patrícia, \\ Jaśkiewicz Marek, Jurecki Rafat
}

\begin{abstract}
Examining the competitiveness of public transport plays an important role because through public transport, the transport of passengers to schools, public healthcare establishments and work is ensured. In addition, transportation for vulnerable groups of passengers (students, seniors) is provided. On the other hand, public transport constitutes a financial burden on public budgets. The aim of this paper is to point out that public transport does not have an equal status in the transport market within the European Union. In the states of Central and Eastern Europe, public transport had a dominant position in the transport market in the 90 s. Nowadays, the market share is declining, particularly in the bus transport, with the rising costs for public budgets regarding an increase in individual motoring. The aim of this paper is to highlight the possibilities of increasing the competitiveness of public transport by integrating different components of public transport. Another aim is to define the possibilities of financing public transport.
\end{abstract}

Keywords: competitiveness, transport, passenger transport, financing, source

JEL Classification: R48, H40

\section{INTRODUCION}

The EU transport strategy prefers the transport of passengers by public passenger transport to individual transport because the use of public passenger transport results in meeting all the goals of the EU strategy in the field of road safety. It relates mainly to the stabilization of the increased road transport claims on infrastructure. This expansion is problematic especially in built-up areas. Construction of a new expressway infrastructure caused by an increasing transport operation is a long-standing problem due to the ageing of population in the EU. The support of public passenger transport brings a lower fuel consumption. This is the way how to attain another objective of the EU strategy in the field of transport, which is the reduction of the EU's dependence on crude oil as a raw material that needs to be imported to the EU. Emission of air pollutants is another strategic goal that is fulfilled due to a lower diesel fuel consumption (Konečný at all, 2016). Based on the considerations from above, it has been concluded that the strategic objectives of the EU transport policy are achieved when population use the public passenger transport. In this regard, it has to be noted that it is necessary to support the public passenger transport and its competitiveness in relation to the individual automobile transport (Poliak, 2013), (Simionescu, 2016). The aim of this paper is to identify the importance of public passenger transport and to define the effective method to increase public transport competitiveness. The increasing fare being dependent on an increasing transport service quality causes a decrease in transport service demand. The price elasticity of transport demand for public mass transport is - 0.32 (Konečný at all, 2016), therefore, the aim 
of the paper is to except the optimization of transport service and to identify possible ways of financing public mass transport from other sources.

\section{PUBLIC TRANSPORT AND ITS POSITION}

"Transportation is often referred to as the lifeblood of cities and regions because it provides the essential link of constantly moving population in this area, thereby helping to shape the region" (Vuchic, 1999). To promote the sustainable and liveable urban environments, private, public and non-motorised transport must functionally complement each other by forming balanced integrated systems.

However, in many cities today, transportation is characterised by the dominance of the cars, it means that there is a high auto-dependence in travel (Klotilda, 2014). As long as there is a sufficient infrastructure available (road and parking), the cars offer convenience of travel to travellers (Ř́ha and Tichý, 2015). The increase in individual automobile transport in towns causes a decrease in travel speed, irregularity of public transport operation and it has also an impact on passengers in public transport. There is also congestion that prevents the accessibility to the destination points, especially those that are located in the city centre.

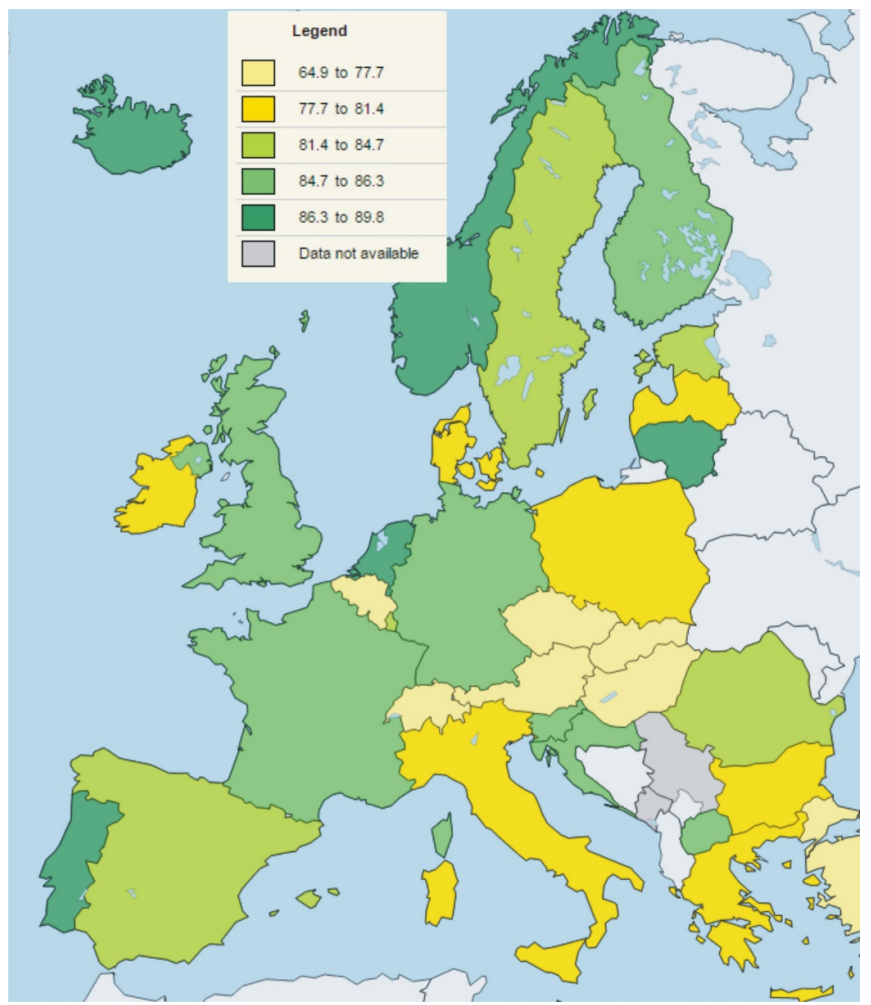

Fig. 1 - The share of personal vehicles' driving performance to total driving performance (2014) 
The increase of individual automobile transport causes other problems such as decreasing road safety, increasing air pollution, traffic noise and global warming (Banister, 2005), (Nedeliakova at all, 2016). While providers of public passenger transport operate only the key areas and places in certain territories, the car users benefit from a high quality of transportation in terms of availability and time (Banister, 2005), (Nedeliakova at all, 2016). Car users usually do not consider the use of land and emission produced by road transport as a problem (Nosal a Starowicz, 2010). However, individual transport causes static problems, too. Parked vehicles are often obstacles for pedestrians, cyclists and the disabled (Nosal a Starowicz, 2010). Concerning these problems, the key issue is to cause a change in people's mobility behaviour towards lower car usage and to encourage them to travel using public means of transport, using more bikes and walk (Nosal a Starowicz, 2010).

The transition of passengers from public transport to individual transport means increasing the negative transport effects on the environment, especially in cities, a nation-wide losses arising congestions (traffic jams), traffic accidents are increasing and the big problems with parking are also growing (Gnap at all, 2006). These are effects, of which solution requires investments from social sources mainly. A driving performance, which is realized by passenger vehicles has a lower share of total performance (Fig. 1 - from 60 per cent to 80 per cent) in Central Europe as compared with the states of Western Europe.

In terms of ensuring efficient transport services system, it is necessary to monitor the evolution of the share of various systems providing transport serviceability. The countries have been divided into two categories by the authors in analysing the share of transportation output. The first category represents more than 80 per cent from 2000 to 2014. It usually regards the states of Western Europe. To the group A the following states belong: Belgium, Denmark, Germany, Ireland, Spain, France, Croatia, Cyprus, Lithuania, Luxemburg, Malta, Italy, Netherlands, Portugal, Finland, Sweden and Great Britain. The other group B has states with the average share of personal vehicles to driving performance that is lower than 80 per cent. The states in the group B are: Bulgaria, Czech Republic, Estonia, Greece, Latvia, Hungary, Austria, Poland, Romania, Slovakia and Slovenia.

Concerning the competitiveness of public transport, this public transport in the group B loses the market share much quicker than in the states in the group A. From Fig. 2, we can state that in the states of the group B, the market share increased from 70.56 per cent to 78.89 per cent in the period from 2000 to 2014 . The market share changed by only about 1.04 percentage point in the states of the group A. 


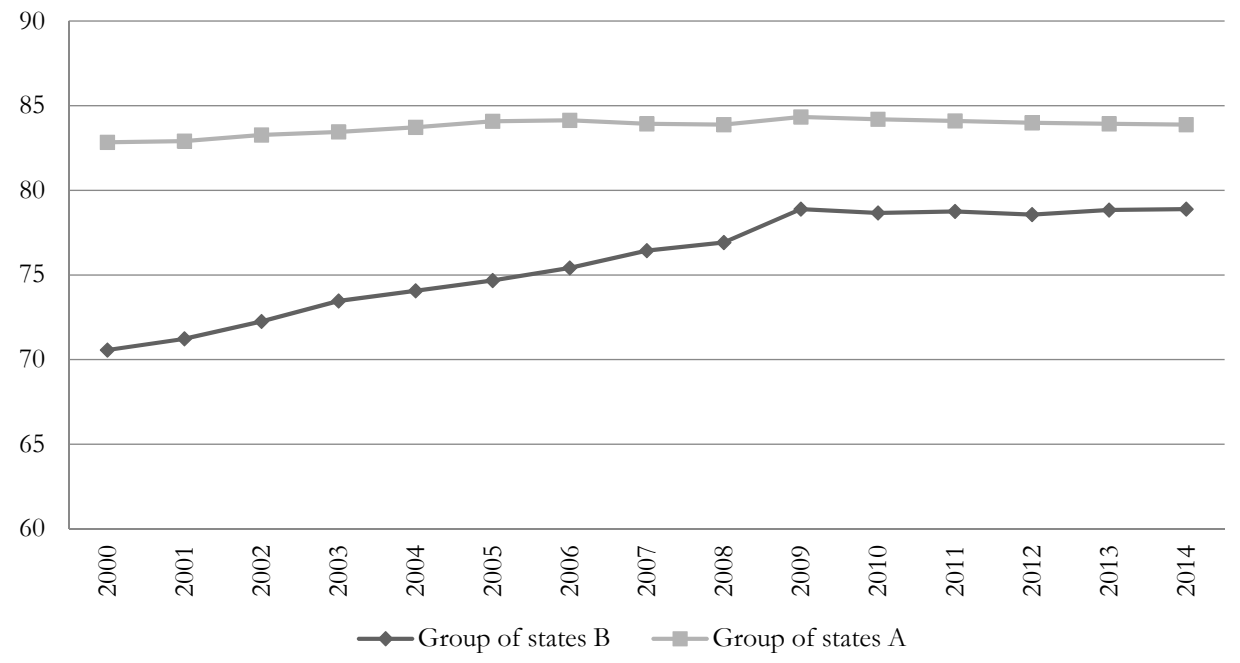

Fig. 2 - The market share of passenger vehicles to transport performance in percentage. Source: processed by authors

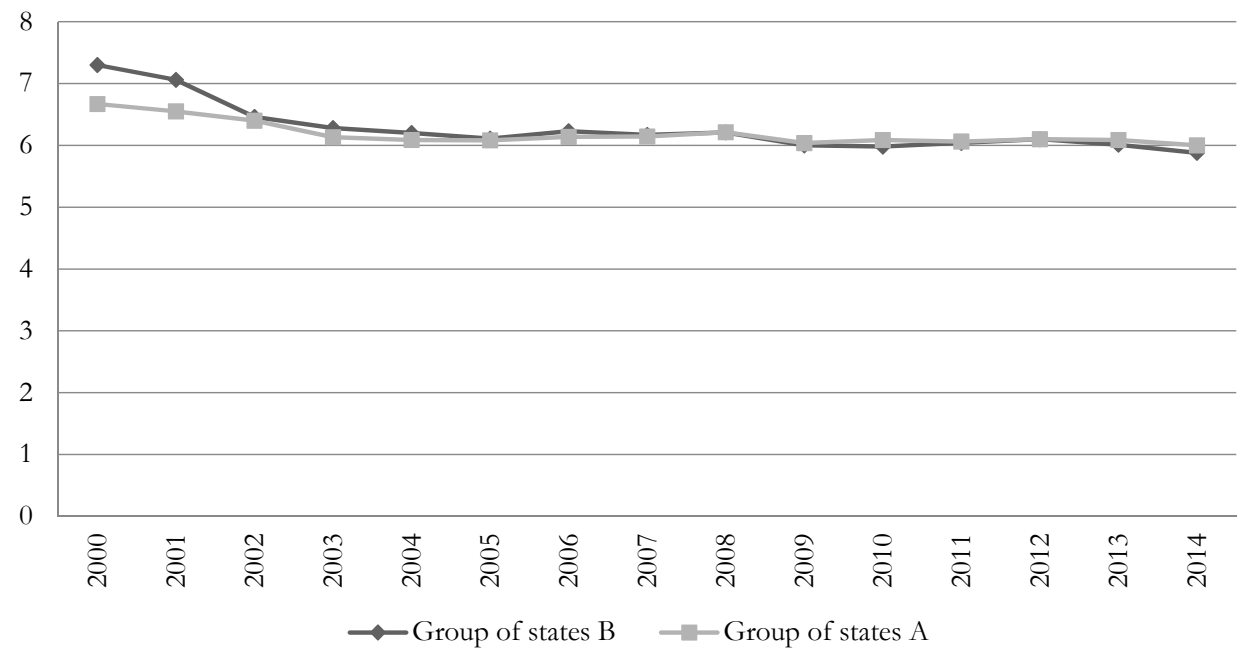

Fig. 3 - The market share of passenger transport by rail to transport performance in percentage. Source: processed by authors 


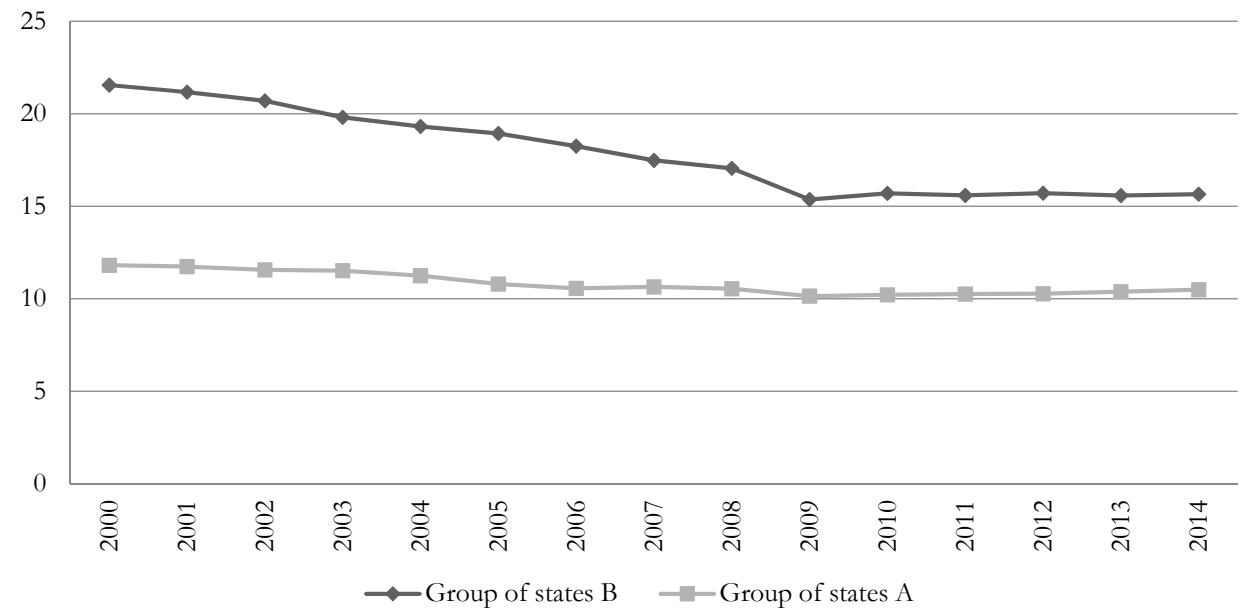

Fig. 4 The market share of bus transport to transport performance in percentage. Source: processed by authors

In the analysis of public transport, we can state that in inland waterway transport, the river transport has inappreciable share of performance (van de Velde, 2008). That is why we are going to deal with bus transport and railway transport. Regarding the market share in railway transport, we can state that the development of market share is nearly identical in both analysed groups of states. In both groups of states, the market share has a decreasing tendency. The difference is only 0.75 percentage point.

There are significant differences between individual groups of states in the analysis of bus transport. The performance decreased about by 1.32 per cent in the group A in the period from 2000 to 2014. The market share decreased by much as 6 per cent in the group B (Fig. 4). On the basis of the processed analysis, we can state that the increase in of the market share of individual car transport in the transport market was because of the share of bus transport.

Based on the analysis, it can be concluded that because of the negatives mentioned resulting from transportation of people by individual automobile transport, it is necessary to increase the competitiveness of public passenger transport, particularly in the states of group B. The requirement is more important in the states where the infrastructure is not ready to share individual motoring in the transport market on a national level of the states of group A.

While operators serve key origins and destinations, it is too costly for them to provide a direct service between all points and it is essential to coordinate different modes of transport in order to ensure smooth, convenient transport services involved in the transfer of passengers (Rivasplata, 2003). To minimise the public passenger transport time, which is greatly influenced by passenger transfer, it is required to integrate public passenger transport that is aimed at coordinating and promoting the continuous transportation of passengers and providing high quality services. Generally speaking, many definitions of public passenger transport integration can be found in the literature of Hine (2000), Ibrahim (2003), Dydkowski (2005), Hull (2005), Preston (2010), but the most popular ones are formulated by Nosal and Solecka (2004) : 
1. Integration is the organizational process, in which the elements of public transport system (network and infrastructure, fares and tickets, information and marketing, etc.) served by various operators who use different modes of transport, interact more efficiently and closely. This results in general improvement in travel conditions and the quality of service.

2. Integration is the way, in which the individual elements of public transport are embedded in the chain of movement.

Commonly, in the urban public transport services, the word 'integration' is used for solutions that guarantee a continuity of "door to door" services (Janic a Reggiani, 2001). Urban transport is to provide an attractive chain of services in the relationship "door to door", making integration to be defined as the combination of Nosal and Solecka (2004):

1. different means of public transport,

2. public and individual transport,

3. transport policy with other policies concerning the spatial planning or investment in infrastructure.

Speaking of the integration of public transport, there it can be taken into consideration the Mohring effect that was defined in 1972: "If more passengers use public transport, the costs per passenger are lower. It means better transport services with a shorter waiting time, denser network of routes and bus stops and shortening walking time. Due to more passengers, it is allowed to plan express links in order to reduce the distance travelled by a vehicle" (Mohring, 1972). At present, the most significant factors in supporting the integration of public transport are road safety and the impact of transport on the environment. The integration of public transport is the latest trend in Western Europe that assumes the increase in attractiveness of public passenger transport (Klotildi, 2014) and the quality of public transport services. On the basis of public passenger transport integration, it is possible to develop a unified system that provides passengers with compatible timetables for different modes of transport. The integration also plays an important role in social policy. According to Nielsen (2005), the importance of transport integration creates an efficient transport system that leads to reduction of traffic congestion and contributes to protection of the environment. In practice, especially in Eastern Europe, it is often about the integration of fares, services and providing information (Poliak at all, 2015).

\section{SOURCES OF FINANCING PUBLIC PASSENGER TRANSPORT}

In general, public passenger transport cannot be financed only from revenue from fares and other revenue, such as advertisement, generated during service provision. This fact was already confirmed by the studies published before 1990; for instance, Bly et al. (1980), Pucher and Markstedt (1983) or Bly and Oldfield (1986). However, the conditions have not changed even at present as it is demonstrated by Tscharaktschiew and Hirte (2012), Poliak (2013) or Drevs et al. (2014). The mentioned studies also point to the fact that the financial support from public funds tends to decrease the level of fares and to increase the frequency of public transport links. Lower fares make public transport more accessible for low-income population groups (Tisato, 1998) as well as groups of people with specific needs such as the disabled and elderly (Asensio et al., 2003). A 
higher financial support from public funds also allows using vehicles with a larger capacity in the provision of transport serviceability (Proost and Dender, 2008).

The most common financial support from public funds (state or local government budget) is in the form of compensation (van de Velde, 2008) that is also referred to subsidies in some literature (Black, 1995). A subsidy or compensation represents a type of payment that does not require a direct ex-change of goods or services in the market economy. It is used to achieve a specific social objective or a specific intended effect (Black, 1995). It represents a payment transfer, however, it is not a gift because there are certain rules that must be kept in order to obtain subsidies for public transport provision.

In most EU member States, public passenger transport is financed traditionally from general taxes (Ubbles and Nijkamp, 2002). The state or a local government generates revenue from various taxes which include direct and indirect taxes. Within the EU, indirect taxes represent, in general, the highest proportion of incomes of state budgets (Poliakova, 2010). With this support, there is no direct link between the source of incomes and their allocation to financing the transport serviceability. The main problem of this form of financing is that there is a considerable competition between the requirements for subsidies from public funds (van de Velde, 2008). Public passenger transport is often financially supported from one budget together with other public services such as education, healthcare, and etc. (Storchmann, 2001). It is very difficult to maintain the financial support of public passenger transport because this support represents high financial resources provided for a long time period. For this reason, new forms of obtaining funds from public sources are being sought in the area of public passenger transport in some states. These are linked to specific incomes of public budgets. The possibilities for a direct connection of public transport financing and the incomes are as follows:

1. Fees for using road infrastructure (Farrell, 1999), (Storchmann, 2001) and (Small and Gomez-Ibanez, 1998),

2. Excise duties (Ubbels and Nijkamp, 2002),

3. Motor vehicle tax (Poliakova, 2010),

4. Income tax for legal entities and natural persons (Wallis et al., 2010) and (Beck et al., 2011),

5. Property tax (Ubbels and Nijkamp, 2002)

6. Parking fees (Predki and Wilk, 1999).

\section{A PROPOSAL TO INCREASE THE COMPETITIVENESS OF PUBLIC PASSENGER TRANSPORT}

Based on the analysis of processing, it is evident that the transport serviceability of public passenger transport cannot be implemented without support from public funds and without an effective cooperation between various kinds of public passenger transport. A proposal to improve the competitiveness of public passenger transport is therefore based on two main instruments. 


\subsection{The proposal of procedure integration of public passenger transport}

According to Vuchic (1999), the most important element of decline in the number of passengers in public passenger transport is an increase in the quality of service. It is required when multiple transfers and the coexistence of more than one operator lead to the necessity of coordination, cooperation and interaction among them to ensure the image of one unified system without confusing potential users or allowing them to notice the interruption in the services offered. To define the integration of public transport, it is necessary to divide it into three levels: organizational, operational and physical integration must be achieved (Klotildi, 2014).

\section{Organizational integration}

One of the conditions necessary for the development of a well-integrated public transport system is that a responsible authority must be given the power to organise the integration of transport service standards (Poliak, Križanová, Semanová, Gajanová, 2014). The established authority is necessary due to the fact that there are several public authorities responsible for transport services in an operating area.

Urban transport serviceability is commonly provided by municipal authorities while regional transport serviceability is provided by regional authorities. For instance, in the Slovak Republic, the regional bus transport is provided by the Office of self-government region - regional authority and regional rail transport is operated by Central Government - Ministry of Transport. The concept of transport serviceability was originated in Hamburg, Germany in 1960.

Originating in Hamburg, it was established the concept of an integrated organisation as a reaction to a declining role of transport in the city's modal split. The concept of an integrated organisation still serves as a public authority that fully coordinates transport services in the region while preserving the individual entities of the component companies which are the ones actually responsible for supplying the services (Pucher and Kurth, 1996).

Unorganised transport serviceability can result in its significant reduction as shown by the cases from Great Britain (Scholler-Schwedes, 2010). Liberalisation of the market in the UK in the 1980s led to the fragmentation of public passenger transport (Preston, 2010) which caused the reduction of public transport serviceability. At present, there are two municipalities in the UK with population of more than 1,000 people that do not have daily regular transport services (Poliak, 2011).

Moreover, organizational integration defines the contracts between the stakeholders ensuring their interest and commitment to the performance of public transport integration system. The established authority must take into account the expectations of public transport passengers, however, according to Rivasplata (2003), the authority must also consider commercial interests of the operators in order to identify clear objectives of integration.

\section{Operational integration}

Operational integration refers to coordination and planning of the transport system with a minimum interruption in space and time in order to satisfy the passengers' expectations. It consists of an integrated network layout, synchronized schedules between different modes and routes of direct transport, integrated information about all services, common fares and convenient ticket- 
ing system (Yiu Kwok Kin, 2005). Greiving and Wegener (Greiving and Wegener, 2003) also highlighted the importance of transport planning. Layout integration refers to planning of the network without spatial discontinuities so that all routes, lines and modes are connected and coordinated in the most efficient way, allowing convenient passengers' transfer. A clear hierarchy and structure of the system are required in combination with defined roles for each mode. Hierarchy promotes services that are easily remembered, uncomplicated, with direct routes when possible, and an efficient coverage of reliable travel routes (Klotildi, 2014). Once the network has been harmonised, the optimization of the system's operation requires an integration of schedules: the coordination and synchronization of arrival and departure times of the lines and modes involved. The aim is to reduce waiting, dwell-time, transfers and total travelling times. Within the operational integration, it is necessary to communicate with passengers (Poliak, Križanová, Semanová, Gajanová, 2014).

A traditional view of transport integration is that travellers perceive transfers as negative experience due to the time, costs and uncertainty (Kingham, 2001). That is the reason why the integrated information system is needed. All necessary information about the entire transport system must be provided, regardless of the mode used and the operator responsible for the service. The way in which the network is presented to the public can significantly affect the effectiveness of the public transport system (Nielsen, 2005). Another key issue within the operational integration is a convenient ticketing system. The integrated system can increase convenience by eliminating the need to purchase a ticket for each trip. Tickets and fares establish a common integration system for the operators involved and contribute to the improvement of transport convenience allowing passengers to travel between lines by purchasing a ticket for the entire service only once. The fares have an impact on both passengers and operators. By introducing a common fare system, the competition between operators can be avoided and the collected revenue can be distributed according to the agreements signed.

There are authors, e.g. Wesolowski (2008), Solecka (2013), that separate the infrastructure integration from the operational integration and consider it as an individual element of integration.

The infrastructure integration consists of an arranged combination of elements that make up the integrity of transport network. It relates to, first and foremost, the elements such as: location of bus stops, stations and interchange junctions for convenient changing of means of transport.

\section{Physical integration}

According to M. Miller (2004), physical or infrastructure integration relates to physical changes such as integration of new routes and reorganization of transfers points. It refers to planning of bus stops, stations and transfer centres, their location and facilities, as well as their design. It also involves the coordination of vehicle movements for transfers to be safe without any conflicts between pedestrians and vehicles movement. Physical integration aims to plan the system carefully through right station design, convenient walking paths and station amenities in order to speed up and secure transfers, improve accessibility towards and inside the intermodal transport system for all traveller groups, facilitate the users' movement and minimize the discontinuities inside the system. 


\subsection{The proposal of financing of public passenger transport sources}

Based on the analysis of conditions in the selected states, it is possible to say that it is necessary to finance public passenger transport from other sources than the revenues from transport. Mostly, the transport services are funded from public budgets, however in many states, the funding of public passenger transport is costly. Apart from traditional sources of financing it is possible to consider unconventional ways of funding (Chromjakova, 2016). In case of these sources, a certain share of taxes or fees is bound to the transport services funding. In the following part, there are identified ways of unconventional transport services financing.

\section{Employee tax and employer tax}

Employer taxes and local income taxes are usually collected by national and local governments around the world, nevertheless, there are some cities in which the taxes are closely linked to payments to the public passenger transport systems. In the United States and Europe, local payroll taxes are used for public passenger transport, e. g. in the United States in Portland and Eugene, Oregon. Oregon permitted local transport authorities to use payroll taxes for generating the revenue. Louisville and Cincinnati use local income taxes to subsidise public passenger transport.

In Europe, employer taxes as a source of financing for transport service are used in France. The first tax collecting was in Paris in 1971 and later, it extended to smaller provincial towns (Farrel, 1999). The tax has to be paid by companies with more than nine employees unless they live in a company precinct or companies provide them with their own transport. A similar way of financing is used by the underground transport in Vienna (Ubbels and Nijkamp, 2002).

\section{Taxes linked to property}

A part of the nature of property tax lies in the concept of providing public passenger transport which brings an advantage to property users (in this case the increase in the property value) (Nedeliakova, Sekulova, Nedeliak and Abramovic, 2016). This mechanism is defined as a mechanism which makes authorities responsible for the development of the city transport infrastructure and allows them to obtain a part of financial benefits from land developers or society. This advantage is reflected in the rise of the real property value which can be considered as a complex index of all advantages formed by development, including better availability and the increase in business opportunities. This process of „recuperation of value” is divided into taxes and single or irregular developer fees. The tax can be defined as a regular property payment and continuous amount to a local or regional government which later allocates subsidies for public passenger transport. Paying for providing public services by the property (or the land) is a common practice in the world and can be observed in whole Europe, Asia and North America. However, in most cases, the resources are collected by authorities and then allocated to each sector according to the actual political purposes. In North America, nevertheless, the allocation of property taxes to fund public transport is common in cities like Minneapolis, New York, Denver, Detroit, Miami, Los Angeles, San Francisco and Vancouver (Bushell, 1994), (Simpson, 1994). Examples of the allocation of property taxes outside North America are rare but can be found in Japan (Osaka), India (Mumbai) and Spain (Barcelona). 


\section{Parking charges and fines}

Parking charges are a common part of our life and they are used by local authorities to finance their activities (Kalasova, Cernicky and Kubikova, 2014). Charges in general cannot be perceived as an unconventional mechanism. However, these charges are rarely hypothecated to support public passenger transport or as a part of a planned transport financing package. There are clear examples in England. In Milton Keynes, revenues of parking charges are dedicated to support public passenger transport which is a part of transport and parking strategy. The example points at the potential of these charges linked to environmental and transport planning processes. There is another programme implemented at the Heathrow, Stansted and Gatwick airports, where passengers contribute an average of $€ 0.31$ from every parking transaction to support public passenger transport. In Amsterdam, revenues from central city parking are used for partial financing of a new traction line. Similar implementations can be found in the world, e. g. Aspen (Colorado), Miami (Florida), La Spezia, Verona and Milan in Italy (Urbels and Nijkamp, 2002).

\section{Local motoring taxes}

A local motoring tax is a tax collected from drivers by local jurisdiction for local purposes (one of them is public passenger transport). It is collected together with the state and federal fuel tax. Motor vehicle taxing is common all over the world (taxes are usually collected nationally) but the revenues are rarely directly allocated (on a local basis) to finance specific objectives. Local motoring taxes may have different forms and they are relatively common in the United States, mainly fuel tax and excise tax.

There are two types of local fuel taxes in Florida - a gas tax approved by voters and a fuel tax approved by the authorities. A local motor vehicle excise tax has been implemented in Washington. It is an annual excise tax on the fair market value of the vehicle. Towns and districts may direct half of the tax revenues for public passenger transport needs. In St. Clara (California), the fuel tax is used to finance the local contribution to the light railway in San José (Simpson, 1994).

Other examples outside the United States are not very known although there are some programmes implemented in Canada as well (e. g. Vancouver, Montreal). In Lisbon (Portugal), public transport is financed from the fees on diesel oil. Since 1967, there has been taxation in Germany allocating $€ 0.026$ from one litre of the sold fuel for investments in city roads and public transport (Urbels and Nijkamp, 2002).

\section{Consumption tax}

In general, the consumption tax is a tax imposed on consumer goods such as general goods, specific services and luxury items and energies, e.g. gas. The consumption taxes may bring dedicated finance resources to transport authorities and through their implementation, the authorities may collect revenues and capital costs for operating. Transport agencies often use taxes to compensate the decreasing state grants, to solve significant investment projects or to supplement operating revenue. This kind of taxes is common in the United States.

The consumption tax in most states in the U.S.A. has the value of 0.5 per cent from the value of the goods. However, it represents a great part of the operation of public passenger transport funding. In some towns, the tax is applicable to any sold goods and the collected tax is used 
to support transport. These kinds of taxes are implemented in Denver, New Orleans, Atlanta, Reno, Fort Worth, Austin and San Francisco Francisco (Black, 1995). Outside the United States, this system of obtaining funds to finance public transport is found in India.

Apart from consumption taxes in the United States, there are also gambling taxes used for financing public passenger transport. The part of revenues from lotteries is assigned for public transport. However, in general, lotteries are perceived as a controversial source of revenue. Critics point at the negatives of gambling - there is a chance for corruption and a high participation rate of poor people. This kind of tax system exists in Maricopa County (Arizona) and in Pennsylvania (Urbels and Nijkamp, 2002).

There are introduced the possibilities of unconventional financing of public mass transport. Based on the statistical data of present conditions (Poliak and Varjan, 2017), up to 65 per cent of sources for public mass transport is necessary to obtain from another sources than from fares. The fare increasing by the price elasticity of demand at the level of -0.32 (Poliak and Varjan, 2017) could support the transfer of travelling people to individual motoring. In case we are focused on necessary financial sources acquisition in conditions of the Slovak Republic only from sources of excise duty of mineral oils, then the tax increasing by $0.09 € /$ litre should cover all financial demands of public mass transport that are set against public government, which were about 233 mil. euros in 2015 ('Table 1).

Tab. 1 - The revenue of petrol tax. Source: Authors'processing

\begin{tabular}{|c|c|c|c|c|}
\hline & Fuel & 2015 & 2012 & 2010 \\
\hline \multirow{3}{*}{$\begin{array}{l}\text { Consumption } \\
\text { in litres }\end{array}$} & Petrol & 736551724 & 747586207 & 888275862 \\
\hline & Diesel & 1855952381 & 1778571429 & 1817857143 \\
\hline & TOTAL & 2592504105 & 2526157635 & 2706133005 \\
\hline \multirow{3}{*}{$\begin{array}{l}\text { Revenue from } \\
\text { excise duty in } \\
\text { euros }\end{array}$} & $\begin{array}{l}\text { Petrol (514.5 } \\
€ / 1000 \text { litre) }\end{array}$ & 378955862 & 384633103 & 457017931 \\
\hline & $\begin{array}{l}\text { Diesel (368 } \\
€ / 1000 \text { litre) }\end{array}$ & 682990476 & 654514286 & 668971429 \\
\hline & TOTAL & 1061946338 & 1039147389 & 1125989360 \\
\hline \multirow{3}{*}{$\begin{array}{l}\text { Income from } \\
\text { the fee of } \\
0.09 € / \text { litre }\end{array}$} & Petrol & 66289655 & 67282759 & 79944828 \\
\hline & Diesel & 167035714 & 160071429 & 163607143 \\
\hline & TOTAL & 233325369 & 227354187 & 243551970 \\
\hline
\end{tabular}

\section{CONCLUSION}

The competitiveness of public passenger transport, especially in Central and East European states, is insufficient. This type of transport, in particular the bus transport sector, has been losing the market share for a longer period of time, and directs to individual automobile transport. With an increase in individual automobile transport exist of various social risks involved of increased costs. In particular, the congestion as it allows 1.2 persons per vehicle on average (Poliak 
at all, 2015). The problem of congestions is often unsolvable in urban areas where there are no possibilities of expansion of the road infrastructure. Another important problem is an accident rate in relation to damages to property or health. At present, there is a significant group of passengers using public passenger transport in Central and Eastern Europe. The role of society is promotion of public passenger transport in such a way that passengers do not leave this transport system. The paper points out how to increase competition of public passenger transport, particularly through creation of integrated transport systems. In the contribution, there are defined the steps necessary to keep during integrated transport systems creation:

- Organizational integration,

- Operational integration,

- Physical integration.

In the contribution, there are listed possibilities of obtaining the necessary funds to finance serviceability from non-traditional sources. The main sources of financing of public passenger transport in Central and East Europe are the following:

- Employee tax and employer tax,

- Taxes linked to property,

- Parking charges and fines,

- Local motoring taxes,

- and mainly the consumption tax.

\section{Acknowledgement:}

This paper was supported by Agentúra na podporu výskumu a vývoja based on the Contract No. SK - PL $-2015-0019$.

\section{References}

1. Asensio, T., Matas, A., \& Raymond, J. L. (2003). Redistributive effects of subsidies to urban public transport in Spain. Transport Reviews, 23 (4), 433 - 452.

2. Beck, A. (2011): Barriers to Entry in Rail Passenger Services: Empirical Evidence for Tendering Procedures in Germany. European Journal of Transport and Infrastructure Research, 11(1), p. $20-41$.

3. Black, A.: Urban Mass Transportation Planning. McGraw-Hill : New York, 1995.

4. Bly, P. H., Webster, F. V., \& Pounds, S. (1980). Effects of Subsidies on Urban Public TranSport. Transportation, 9 (4), 311-331.

5. Bly, P. H., \& Oldfield, R. H. (1986). Competition between minibuses and regular bus service. Journal of Transport Economics and Policy, 20 (1), 47-68.

6. Banister, D. 2005. Unsustainable transport. City transport in the new century. London: Routledge.

7. Bushell, C. (1994). Jane's Urban Transport Systems 1993=94, Jane’s Information Group. Coulsdon: Surrey. 
8. Drevs, F., Tscheulin, D. K., Lindermeier, J., \& Renner, S. (2014): Crowding-in or crowding-out: An empirical analysis on the effect of subsidies on individual willingness-topay for public transportation. Transportation Research Part A, 59(1), 250 - 261.

9. Dydkowski, G., (2005). Integracja lokalnego transportu zbiorowego. Zeszyty Naukowe Politechniki Śląskiej, Transport 60.

10. EUROSTAT (2014). The share of personal vehicles' driving performance to total driving performance. Retrieved from: http://ec.europa.eu/eurostat/web/transport/data/maintables.

11. Farrell, S. (1999). Financing European Transport Infrastructure: Policies and Practice in Western Europe. London: Macmillan. ISBN 033-37-189-68.

12. Gnap, J., Konečný, V., \& Poliak, M. (2006): Elasticita dopytu v hromadnej osobnej doprave. Ekonomický časopis/Journal of Economics, 54 (7), 668 - 684.

13. Greivinmg, S., \& Wegener, M. (2003). Integration of Transport and Land Use Planning: State of the Art. Proc. of the Ninth World Conference on Transport Research. Elsevier: Amsterdam.

14. Hine, J. (2000). Integration integration integration ... Planning for sustainable and integrated transport systems in the new millennium. Pergamon. Transport Policy 7.

15. Hull, A., (2005). Integrated transport planning in the UK: from concept to reality. Journal of Transport geography, 13 (1), 318-328.

16. Chromjaková, F. (2016). The Key Principles of Process Manager Motivation in Production and Administration Processes in an Industrial Enterprise. Journal of Competitiveness, 8 (1), 95 -110 .

17. Ibrahim, M.F. (2003). Improvements and integration of a public transport system: the case of Signapore. Cities, 20 (3), 205-216.

18. Janic, M., \& Reggiani, A. (2001). Integrated transport systems in European Union: An overview of some recent developments. Transport Reviews, 2 (4), 469-497.

19. Kalasova, A., Cernicky, L., \& Kubikova, S. (2014). Microscopic Simulation of Coordinated Route in the City of Zilina, Communications - Scientific Letters of the University of Zilina, 16(2), 46-50.

20. Kingham, S., et al. (2001). Travelling to Work: will People Move out of their Cars. Transport Policy, 8(2), 151-160.

21. Klotildi, S. (2014). Public Transport Integration: The Case Study of Thessaloniki. Transportation Research Procedia, 4(1), 535-552.

22. Konečný, V., Gnap, J., \& Šimková, I. (2016). Impact of fiscal decentralization on motor vehicle taxation in the Slovak Republic. Transport and telecommunication, 17 (1), 28-39.

23. Miller, M. A. (2004). Assessment of Service Integration Practices for Public Transportation: Review of the Literature. California Partners for Advanced Transit and Highways.

24. Mohring, H. (1972). Optimisation and scale economies in urban bus transportation. American Economic Review 62, 591-604. 
25. Nedeliakova, E., Sekulova, J., Nedeliak, I., \& Abrahimovic, B. (2016). Application of Raymond Fisk Model in Research of Service Quality, Communications - Scientific Letters of the University of Zilina, 18 (2), 11-14.

26. Nielsen, G., et al. (2015) HiTrans Best Practise Guide 2: Public Transport-Planning the Networks. HiTrans.

27. Nosal, K., \& Solecka, K. (2014). Application of AHP method for multi-criteria evaluation of variants of the integration of urban public transport. Transportation Research Procedia, 10(3), $269-278$.

28. Nosal, K., \& Starowicz, W. (2010). Wybrane zagadnienia zarządzania mobilnością. Transport Miejski i Regionalny 3.

29. Poliak, M. (2011). Marketing in Public Passenger Transport. Perner's Contacts, 6 (4), 320-325.

30. Poliak, M. (2013). The Relationship between the Fair Profit and Risk in the Public Passenger Transport in the Slovak Republic. Ekonomicky casopis/Journal of Economics, 61 (2), 206-220.

31. Poliak, M. (2013). Relationship of reasonable profit and risk in public passenger transport in the Slovak Republic (in Slovak). Ekonomicky casopis/Journal of Economics, 61 (2), 206-220.

32. Poliaková, A. (2010). Dane a poplatky v doprave a zasielatelstve. Zilina: EDIS-publisher ZU.

33. Poliaková, A. (2010). Customer satisfaction index with a quality of service in public mass transport. Doprava a spoje 2(1), 43-49.

34. Poliak, M., Krizanova, A., Semanova, S., Gajanova, L. (2014). The Influence of Contract Form Choice of the Transport Services Ensuring on Performance Contracting Entity Requirement, Transport Problems = Problemy Transportu: International Scientific Journal, 9 (4), 153 161.

35. Poliak, M., Semanová, Š., \& Poliaková, A. (2015). Risk allocation in transport public service contracts $=$ Alokacija rizika u ugovorima o uslugama u javnom prometu. Ekonomski Pregled, 66 (4), 384-403.

36. Poliak, M., \& Varjan, P. (2016). Netradičné spôsoby financovania dopravnej obslužnosti hromadnou osobnou dopravou. In: Proceedings CMDTUR 2016: 7. medzinárodnej vedeckej konferencie Žilina 19.10.-20.10.2016. Žilinská univerzita.

37. Predki, B., \& Wilk, Sz. (1999). Rough set based data exploration using ROSE system. In: Foundations of Intelligent Systems. 11th International Symposium, ISMIS’99 Warsaw, Poland, June 8-11, 1999., 172 - 180.

38. Preston, J. (2010). What's so funny about Peace, Love and Transport Integration? Research in Transportation Economics, 29 (1), 329- 338.

39. Proost, S., \& K. van Dender (2008). "Optimal urban transport pricing in the presence of congestion, economies of density and costly public funds", Transportation Research Part A - Policy and Practice, 42 (9), 1220-1230.

40. Pucher, J., \& Kurth, S. (1996). Verkehrsverbund: The Success of Regional Public Transport in Germany, Austria and Switzerland, (E. S. Ltd, Ed.). Transport Policy, 2(1), 279-291. 
41. Pucher, J., \& Markstedt, A. (1983). Consequences of Public Ownership and Subsidies for Mass Transit: Evidence from Case Studies and Regression Analysis. Transportation, 11 (4), 323-345.

42. Rivasplata, C. (2003). Three Perspectives on the Role of Competitive Tendering in the Integration of Public Transport. 22nd Southern African Transport Conference, Pretoria: South Africa: Southern African Transport Conference (SATC).

43. Říha Z., \& Tichý, J. (2015). The Costs Calculation And Modelling In Transport. Transport Means, 2015, 388-391.

44. Scholler-Schwedes, O. (2010) The Failure of Integrated Transport Policy in Germany: A Historical Perspective. Journal of Transport Geography, 18 (1), 85-96.

45. Simionescu, M. (2016). Competitiveness and Economic Growth in Romanian Regions. Journal of Competitiveness, 8 (4), 46 - 60.

46. Simpson, B. J. (1994). Urban Public Transport Today. E\&FN Spon : London.

47. Small, Kenneth A., \& José A. Gómez - Ibánez. (1998). Road pricing for congestion management: the transition from theory to policy. Button and Verhoef, $213-46$.

48. Solecka, K. (2013). Multi-criteria assessment of possibilities for integrated system of urban public transport (in Poland), Phd thesis. Politechnika Krakowska.

49. Storchmann, K. H. (2001). The impact of fuel taxes on public transport - an empirical assessment for Germany. Transport Policy, 8 (1) $19-28$.

50. Tisato, P. (1998): Service unreliability and bus subsidy. Transportation Research A: Policy Practice, 32 (6), 423 - 436

51. Tscharaktschiew S., \& Hirte, G. (2012). Should subsidies to urban passenger transport be increased? A spatial CGE analysis for a German metropolitan area. Transportation Research Part A, 46(1), 285-309.

52. Ubbels, B., \& Nijkamp, P. (2002) Unconventional Funding of Urban Public Transport. Transportation Research, Part D, 7 (1), 317-329.

53. Van de Velde, D. (2008). A New Regulation for the European Public Transport. Research in Transport Economics, 22 (1), pp. $78-84$.

54. Vuchic V. R. (1999) Transportation for Livable Cities. New Jersey: Rutgers.

55. Wallis, I., Bray, D., \& Webster, H. (2010): To Competitively Tender or to Negotiate Veighing Up the Choices in a Mature Market. Research in Transport Economics, 29 (1), 89 - 98.

56. Wesolovski, J. (2008). A city in motion. Best practices in the organization of urban transport(in Poland). Lodz: Instytut Spraw Obywatelskich.

57. Yiu Kwok Kin, A. (2005). An Integrated Public Transport System - A Case Study of Hong Kong. the University of Hong Kong,

58. Internal data of Financial Administration Slovak Republic

59. Internal data of Ministry of economy of the Slovak Republic. 


\section{Contact information}

Milos Poliak

Department of Road and Urban Transport, Faculty of Operation and Economics of Transport and Communications, University of Zilina, Zilina, Slovakia

Univerzitna 1, 01026 Žilina, Slovak. Republic

Email:milos.poliak@fpedas.uniza.sk.

Adela Poliaková

Tomas Bata University in Zlin

Faculty of Management and Economics

Mostni 5139, Zlin, 760 01, Czech Republic

Email:poliakova@fame.utb.cz.

Michaela Mrníková

Department of Road and Urban Transport, Faculty of Operation and Economics of Transport and Communications, University of Zilina, Zilina, Slovakia

Univerzitna 1, 01026 Žilina, Slovak Republic

Email:michaela.mrnikova@fpedas.uniza.sk

Patricia Simurková

Department of Road and Urban Transport, Faculty of Operation and Economics of Transport and Communications, University of Zilina, Zilina, Slovakia

Univerzitna 1, 01026 Žilina, Slovak Republic

Email:patricia.simurkova@,fpedas.uniza.sk.

Marek Jaskiewitr.

Kielce University of Technology

Faculty of Mechatronics and Machine Design,

al. Tysiaclecia Państwa Polskiego 7, Kielce, 25-314, Poland

Email:m.jaskiewicz@tu.kielce.pl

Rafat Jurecki

Kielce University of Technology

Faculty of Mechatronics and Machine Design,

al. Tysiaclecia Państwa Polskiego 7, Kielce, 25-314, Poland

Email: rjurecki@tu.kielce.pl 